\title{
COMMENTARY
}

\section{Clinical comparability and European biosimilar regulations}

\author{
Huub Schellekens \& Ellen Moors \\ Clinical trials required by European regulators to compare biosimilar products with corresponding biologic brands are \\ surplus to requirements and may even be a barrier for the development of biosimilars of more complicated biologics.
}

n 2004, the European Union (EU; Brussels) adopted legislation to establish a comprehensive regulatory pathway for bringing biosimilars to market. Currently, the European Commission has approved six of these products. On the basis of the European Public Assessment Reports (EPARs), which summarize the regulatory data used as a basis for granting marketing authorization, the quality of the biosimilars seems to be equal to or better than the originals. The mandatory clinical trials outlined in the regulations have shown these products to be effective and safe. Even so, the guidelines also require a comparability exercise intended to show the quality, safety and efficacy of the biosimilar to be comparable to the original product. We contend that this comparability exercise is of debatable value; indeed, it may even be a barrier for the development of biosimilars of more complicated biologics. For this reason, we suggest that the requirement for comparability studies for biosimilars be dropped. At the same time, the revised regulatory pathway used in the EU should be expanded to include complex pharmaceuticals other than biologics.

\section{Biosimilars emerge}

The first recombinant DNA-derived therapeutic proteins were introduced in the 1980s. These were mainly copies of endogenous human proteins, such as erythropoietin (EPO), insulin, growth hormones and cytokines. Such recombinant proteins were followed by the

Huub Schellekens is in the Departments of Pharmaceutical Sciences and Innovation Studies and Ellen Moors is in the Department of Innovation Studies, Utrecht University, Utrecht, The Netherlands.

e-mail:h.schellekens@uu.nl first monoclonal antibodies (mAbs) produced by hybridoma technology_ products that have become important treatment options in clinical practice for many diseases, including anemia, diabetes, cancer, hepatitis and multiple sclerosis $^{1}$.

The patents for many of these first wave of biopharmaceuticals have expired or are about to expire, opening the possibility for marketing noninnovator versions of these products. When the patent of a classic small-molecule drug expires, generics may be marketed if their therapeutic equivalence to the original drug has been established. Conventional generics are considered to be therapeutically equivalent to a reference once pharmaceutical equivalence (that is, identical active substances) and bioequivalence (that is, comparable pharmacokinetics) have been established and do not require formal clinical efficacy and safety studies. This relatively modest requirement is one of the major reasons generics can be marketed far below the price of innovator drugs.

The generic approach cannot, however, be applied to copies of therapeutic proteins because of their complexity. After a fierce debate between regulatory bodies, the brand biotech industry and companies planning to introduce noninnovator versions of protein drugs, a consensus was reached on the need for clinical data to substantiate the clinical equivalence of these products.

Because it is impossible to show two protein products to be identical, the term 'biosimilars' was introduced in the EU and 'follow-on protein products' or 'biogenerics' in the United States. Pioneering law in this area, the EU adopted legislation in 2004 to establish a comprehensive regulatory pathway for bringing biosimilars to market. Subsequently, the European Medicine
Agency (EMEA, London) and its scientific Committee for Medicinal Products for Human Use (CHMP) developed guidance documents to provide more detail on the requirements ${ }^{2-9}$; the United States is expected to establish similar pathways in the coming months ${ }^{10}$ that allow separate marketing approval after patent expiration and adopt other provisions to protect intellectual property, such as data exclusivity of the reference products ${ }^{3,11-13}$. To be allowed on the market, the biosimilar product should be shown to be similar to the reference product in terms of quality, safety and efficacy.

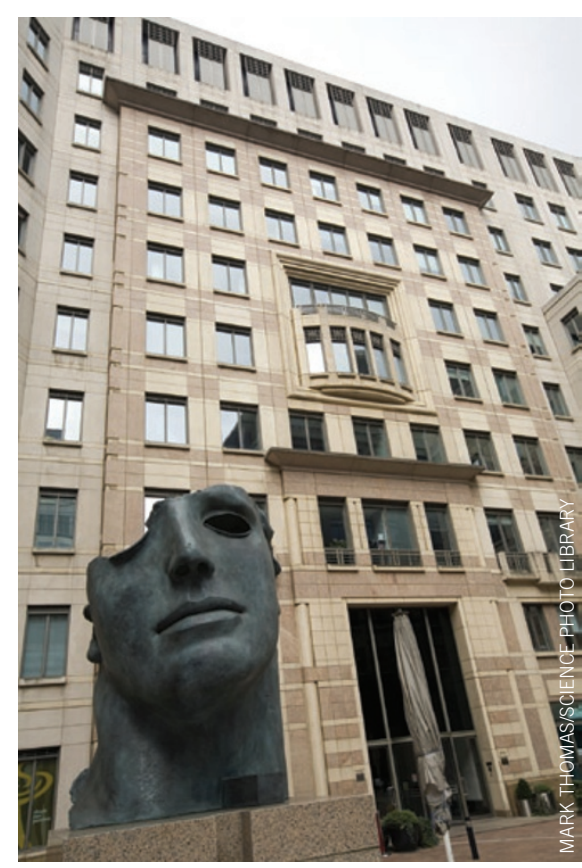

The EMEA (headquarters in Canary Wharf, London, pictured here) has pioneered the regulatory oversight of biosimilars. 
Table 1 Different biosimilars in the EU in March 2009

\begin{tabular}{lll} 
International generic name & Brand name reference product & Trade name biosimilar \\
\hline Somatotropin & Genotropin & Omnitrope \\
Somatotropin & Humatrope & Valtropin \\
Epoetin alfa & Eprex & Abseamed, Binocrit and Epoetin alfa Hexal \\
Epoetin zeta & Eprex & Retacrit and Silap \\
Filgrastim & Neupogen & Biograstim, Filgrastim, Ratiopharm, \\
& & Ratiograstim and Tevagrastim \\
\hline Filgrastim & Neupogen & Filgrastim Hexal and Zarzio
\end{tabular}

Currently, based on advice from the EMEA CHMP, the European Commission (Brussels) has approved biosimilar versions of recombinant somatropin ${ }^{14,15}$, recombinant human $\mathrm{EPO}^{16-}$ 20 and recombinant filgrastim ${ }^{21,22}$ (Table 1; the EPARs summarizing product characteristics and a scientific discussion of the data supporting each EMEA approval can be found in refs. 22-30).

Not all biosimilar applications have been successful thus far. The European regulator rejected Alpheon, a biosimilar version of interferon (IFN)- $\alpha-2 \mathrm{a}$ (ref. 31 ); and another biosimilar application concerning three different human insulin formulations was withdrawn in 2008 by Marvel Lifesciences (Mumbai, India) ${ }^{32}$.

On the basis of our analysis of the criteria that the EMEA CHMP has applied to the evaluation of biosimilars and the strengths and weaknesses of European regulations, we consider in the following sections the question of whether the biosimilar regulatory pathway should be expanded to other complex pharmaceuticals than biologics.

\section{What is a biosimilar?}

Neither the EU legislation nor the EMEA CHMP guidelines provides a definition of a biosimilar other than it is a product comparable in quality, safety and efficacy to a reference product. The acceptable differences between biosimilar and reference products in these three major attributes are not stated. Thus, only the evaluation of what the EMEA CHMP accepts and rejects will define what a biosimilar is.

Table 2 lists the types of differences between a biosimilar and innovator product that have been allowed thus far by the EMEA CHMP. The list includes completely different host cells and formulations, differences in the level of impurities and in the types and levels of glycosylation. These variations are known to have the potential to have a major effect on a product's clinical efficacy and safety. The clinical studies of biosimilars tested thus far, however, have shown that for the products under review, these differences have not compromised efficacy or influenced the level of adverse drug reactions in humans compared with the brand product.
Thus, the clinical data, which are mandatory for a marketing authorization request for biosimilars, enable evaluation of the biological consequences of both the differences found in the aspects of the biologics that can be characterized and the aspects that are missed by current analytical tools.

What's more, when the CHMP/EMEA's evaluations to date are examined, any difference in host cell expression system, purity and formulation appears acceptable if the clinical data show no negative effect. This raises the question of whether a comparison of the quality attributes of a biosimilar with the reference product is relevant.

\section{The preclinical and clinical comparability exercise}

The foundation of the EMEA CHMP regulatory framework for biosimilars is the EU legislation in the Human Code of 2004 (ref. 2). This stipulates that biologics recalcitrant to full characterization not only fall outside of traditional generic regulations but also require supplementary preclinical testing or human trials. An important part of the documentation for classic generics is comparative pharmacokinetic data. These data are also expected in a biosimilar approach. With classic generics, the comparative pharmacokinetic data are a surrogate for clinical trials. In contrast, for a biosimilar marketing application, clinical data are mandatory. This raises the question of why the comparative pharmacokinetic data are needed.

For classic small-molecule drugs, an $80-125 \%$ acceptance range for comparative pharmacokinetic data is used by regulators. According to the EMEA CHMP guidelines,

Table 2 Quality differences between biosimilars and reference drug products

\begin{tabular}{llll} 
Different host cells & Different levels of impurities & Different formulation & Different glycosylation \\
\hline Valtropin & $\begin{array}{l}\text { Abseamed, Binocrit and } \\
\text { Epoetin alfa Hexal }\end{array}$ & Retacrit and Silap & $\begin{array}{l}\text { Abseamed, Binocrit and } \\
\text { Epoetin alfa Hexal }\end{array}$ \\
& Zarzio and Filgrastim Hexal & $\begin{array}{l}\text { Biograstim, Filgrastim, Retacrit and Silap } \\
\text { Ratiopharm, Ratiograstim } \\
\text { and Tevagrastim }\end{array}$ & \\
& & Zarzio and Filgrastim \\
& &
\end{tabular}

this range does not apply to biosimilars and a range specific to every product should be predefined and justified. However, for many if not all biotech-derived therapeutic proteins, this either is impossible or can be established only in extensive clinical trials.

In practice no equivalence margin has been predefined in any of the studies of the biosimilars; mostly, the classic acceptance range of $80-125 \%$ was used post hoc (Table 3). In the majority of cases, either comparative pharmacokinetic data were not provided at all or one or more parameters were not within this post hoc defined acceptance range. In all cases, however, the EMEA CHMP has accepted these results based on the argument that clinical trials are required to demonstrate comparable efficacy and safety. The agency has also not provided a scientific and regulatory rationale for comparative pharmacokinetics.

The same holds true for clinical comparability. The usefulness of these studies is debatable (Table 3). In fact, only in the case of filgrastim were the direct clinical comparisons between biosimilar and innovative product done according to the regulations. In all other cases, this comparison was either lacking or incomplete or data showed that the biosimilar actually lacked clinical comparability!

\section{Biosimilars rejected or withdrawn}

Alpheon, a biosimilar version of Roferon-A (IFN- $\alpha-2 a$ ), was rejected by the EMEA in June 2006. The reasons included quality and clinical differences between Alpheon and the reference product, inadequate data on the stability of the active substance, inadequate validation of the process for the finished product and insufficient validation of immunogenicity testing ${ }^{31}$.

Another biosimilar application concerning three different human insulin formulations with Humulin as reference product was withdrawn by Marvel ${ }^{32}$. The main concerns of the CHMP were that the comparability of the Marvel insulins and the Eli Lilly (Indianapolis) Humulin insulins had not been shown and the Indian company had not supplied enough information on how the active substance or the finished products were made and that the processes used to make them had not been validated. 
That said, in the cases of the biosimilar IFN- $\alpha 2 \mathrm{a}$ and Marvel insulins, there were not only major comparability issues but also other problems such as validation of analytical tools. So it remains a question whether the comparability issues alone would have resulted in a negative opinion of the CHMP.

\section{The scope of the EU biosimilar regulations}

With the exception of a few small peptides like somatostatin and calcitonin, it is impossible with current technology to fully characterize biologics, including highly purified biotechnologically derived therapeutic proteins, such as somatotropin, epoetins and filgrastim. Copies of these latter molecules were the first biosimilars to be approved by the European Commission under a new regulatory pathway. Even so, some inconsistencies remain.

The current European biosimilar regulatory pathway is restricted to biologics but apparently not all copies of biologic molecules qualify. The EMEA CHMP guidelines state that comparability exercises to demonstrate similarity are more likely to be applied to highly purified products, which can be thoroughly characterized (e.g., biotech-derived medicinal products), than to other types of biologics. The implicit assumption is, therefore, that the pathway does not apply to more poorly purified biologics that are even more complex and difficult to characterize than a highly purified recombinant biologic. This seems to contradict the rationale that biologic complexity, and our inability to adequately characterize complex proteins, necessitates the comparability exercise.

Biologics are defined in the EMEA CHMP guidelines as products of living cells. There are, however, other compounds that are as complex as biologics, whose characteristics are also highly dependent on the production process and which are impossible to characterize fully.

A good example is glatiramer acetate (Copaxone), which is used for the treatment of multiple sclerosis. Glatiramer acetate is a member of the glatiramoid class of products. It is the acetate salt of synthetic polypeptides containing four naturally occurring amino acids: L-glutamic acid, L-alanine, L-lysine and L-tyrosine. The glatiramer acetate in Copaxone is not a single molecular entity but rather a heterogeneous polypeptide mixture that contains a huge, perhaps incalculable number of polypeptides, which has not been fully characterized.

The precise mechanisms by which the Copaxone product exerts its pharmacological effects in individuals with multiple sclerosis are not fully elucidated but the drug is presumed to act as a modulator of the immune

\section{Table 3 Preclinical and clinical equivalence discrepancies}

\begin{tabular}{ll}
$\begin{array}{l}\text { Pharmacokinetics not according to guidelines and/ } \\
\text { or outside acceptance range }\end{array}$ & $\begin{array}{l}\text { Clinical trials not according to guidelines and/or } \\
\text { showing differences }\end{array}$ \\
\hline Omnitrope (no comparison with reference product) & $\begin{array}{l}\text { Omnitrope (no direct comparison with reference } \\
\text { product) } \\
\text { Valtropin (only partial comparison with reference } \\
\text { product) }\end{array}$ \\
$\begin{array}{l}\text { Abseamed, Binocrit and Epoetin alfa Hexal } \\
\text { (acceptance range not predefined, AUC after iv }\end{array}$ & $\begin{array}{l}\text { Abseamed, Binocrit and Epoetin alfa Hexal (no } \\
\text { treatment outside range) }\end{array}$ \\
$\begin{array}{l}\text { Retacrit and Silap (acceptance range not } \\
\text { predefined. Correction needed to meet range) }\end{array}$ & $\begin{array}{l}\text { Retacrit and Silap (no comparison of subcutaneous } \\
\text { administration; no comparability for mean dosage) }\end{array}$ \\
$\begin{array}{l}\text { Filgrastim Hexal and Zarzio (at the lower doses and } \\
\text { after a multiple subcutaneous dose of } 5 \mu g / k g \text { out- } \\
\text { side acceptance range) }\end{array}$ & \\
\end{tabular}

system $^{33}$. Upon subcutaneous injection, Copaxone degrades into smaller peptides and free amino acids locally, resulting in low or undetectable serum concentrations of the drug or its metabolites. Moreover, glatiramer acetate need not be in the systemic circulation to exert its anti-inflammatory effects.

There have been attempts to develop a generic version of Copaxone (Fig. 1), which clearly failed. Analysis of different batches of this attempted generic also showed big differences between batches illustrating the difficulties in consistently producing this type of product.

Another example is the iron-sucrose complex (Venofer) that is used for the intravenous treatment of iron deficiencies. Recently, several copies of Venofer have been introduced that differ slightly in physical chemical characteristics and show considerable differences in efficacy and safety ${ }^{34}$.

Considering the complexity of Copaxone and Venofer, it seems reasonable that they should be excluded from the EMEA's generic pathway. Taking this further, it seems reasonable that the biosimilar pathway should not be restricted just to biologics but should be applicable to all medicinal products that are complex and difficult to characterize.

\section{Conclusions}

Europe was the first region in the world with a comprehensive legislative and regulatory pathway for the introduction of biosimilars. The two cornerstones of the EMEA CHMP guidelines are the need for clinical data and the comparability exercise to show biosimilarity in quality, efficacy and safety. Six biosimilars have been approved under this pathway. Their evaluation as described in EPARs confirms the need for clinical data to confirm the efficacy and safety of these products.

Even so, in our opinion, the merits and/ or added value of the comparability exercise are questionable. The comparison of quality characteristics between the biosimilar and the reference product will always show differences. And with the improvement of the analytical tools, our ability to find differences will only increase. In most cases, the consequences of these differences are unknown; for example, how does one assess the effects of a reduced level of $O$-glycosylated isoform in epoetin zeta compared with Eprex? In any case, the quality differences become irrelevant if the clinical data show the biosimilar to be clinically equivalent to the reference product.

According to the EPARs, the biosimilar epoetin alfa and one of the biosimilar filgrastims

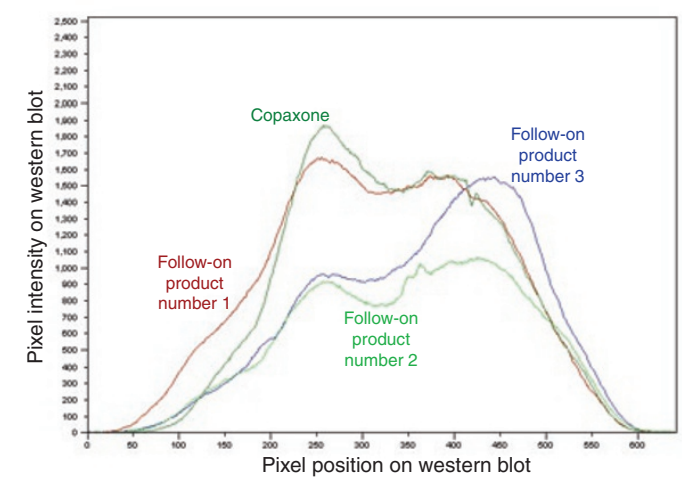

Figure 1 Western blot analysis of Copaxone and three follow-on products. Reprinted by permission of Teva Pharmaceuticals. 
have fewer impurities and less modified product than their reference products. We have recently analyzed the physical chemical characteristics of both biosimilar epoetins and have found the quality of these biosimilars to exceed the original product.

An additional aspect for regulators to consider is technology obsolescence. Since the introduction of the first recombinant DNAderived therapeutic proteins, the technology to produce and purify these products has greatly improved. Biosimilar manufacturers are consequently using state-of-the-art technology; in contrast, brand manufacturers of the original products are often locked into old technologies because changing methods has major financial and regulatory consequences. With this in mind, it seems much more logical for regulators to expect biosimilars to be produced by the best technology on offer rather than to mandate that they are of comparable quality to the brands.

Furthermore, there are many reasons to question the usefulness of comparative pharmacokinetic trials. The assays to determine product levels are often too imprecise; the relation between pharmacokinetic parameters and clinical effect of biologics is unclear; the dose-response curve of therapeutic proteins is often bell shaped (meaning that widely differing protein levels have the same clinical effect); and the acceptance range for pharmacokinetics parameters between biosimilar and reference product are difficult or impossible to predefine and justify.

The regulatory demand for clinical comparison between biosimilar and reference product is also questionable considering the practical consequences. The majority of biosimilars approved did not meet the conditions of the different guidelines mainly because of reasons beyond the control of both the regulators and the manufacturers of the biosimilars; indeed, in one case, a direct comparison between the biosimilar and the reference product was completely absent in the dossier. Apparently, contrary to the regulations, a direct clinical comparison is not essential for evaluating the clinical efficacy and safety of a biosimilar.

Removing the mandatory comparability exercise from the guidelines does not mean that comparisons between biosimilar and original product are not important during their development. Manufacturers do comparisons between their biosimilars and the original products to set specifications for their production and puri- fication and to validate their production methods and analytical tools. Comparative data may also be helpful for a biosimilar manufacturer to claim extrapolation of indication. And it may be important for marketing reasons.

Dropping the obligation to do the comparability exercise will also make it easier to develop more complex biosimilars, such as mAbs and vaccines, and will avoid the ethical and practical problems concerning the comparability studies of products with survival as the primary clinical end point.

European legislators and regulators have had the courage to be the first to introduce a pathway for the introduction of biosimilars. This has enabled the introduction of six high-quality products and also the possibility to evaluate the strengths and weaknesses of the regulations. We urge regulators to consider the experience with the first biosimilars to streamline current regulations and apply an even playing field so that the same regulatory principles are applied to complex pharmaceuticals other than recombinant proteins.

\section{COMPETING INTERESTS STATEMENT}

The authors declare competing financial interests: details accompany the full-text HTML version of the paper at http://www.nature.com/naturebiotechnology/.

1. Avidor, Y., Mabjeesh, N.J. \& Matzkin, H. South Med. J. 96, 1174-1186 (2003).

2. European Parliament and Council. Off. J. Eur. Union 47, 34-57 (2004).

3. Anonymous. Guideline on similar biological medicinal products. (EMEA, London, 2005; accessed 4 March 2008). <http://www.emea.europa.eu/pdfs/human/ biosimilar/043704en.pdf $>$

4. Anonymous. Guideline on similar biological medicinal products containing biotechnology-derived proteins as active substance: quality issues. (EMEA, London, 2006; accessed 4 March 2008). <http://www.emea.europa.eu/ pdfs/human/biosimilar/4934805en.pdf>

5. Anonymous. ANNEX to guideline on similar biological medicinal products containing biotechnology-derived proteins as active substance: non-clinical and clinical issues guidance on similar medicinal products containing recombinant erythropoietins. (EMEA, London, 2006; accessed 4 March 2008). <http://www.emea.europa.eu/ pdfs/human/biosimilar/9452605en.pdf>

6. Anonymous. Annex to guideline on similar biological medicinal products containing biotechnology-derived proteins as active substance: non-clinical and clinical issues guidance on similar medicinal products containing somatropin. (EMEA, London, 2006; accessed 4 March 2008). <http://www.emea.europa.eu/pdfs/human/ biosimilar/9452805en.pdf>

7. Anonymous. Annex to guideline on similar biological medicinal products containing biotechnology-derived proteins as active substance: non-clinical and clinical issues guidance on similar medicinal products containing recombinant human soluble insulin. (EMEA, London, 2006; accessed 4 March 2008). <http://www.emea. europa.eu/pdfs/human/biosimilar/3277505en.pdf>

8. Anonymous. Annex to guideline on similar biological medicinal products containing biotechnology-derived proteins as active substance: non-clinical and clinical issues guidance on similar medicinal products containing recombinant granulocyte-colony stimulating factor. (EMEA, London, 2006; accessed 4 March 2008). <http://www.emea.europa.eu/pdfs/human/ biosimilar/3132905en.pdf>

9. Anonymous. Similar biological medicinal products containing biotechnology-derived proteins as active substance: Non-clinical and clinical issues. CHMP/42832/05 <http://www.emea.europa.eu/pdfs/ human/biosimilar/4283205en.pdf> (Accessed 21 December 2009)

10. <http://www. patentdocs.org/2009/12/followon-biologicsnews-briefs-no-10.html>

11. Crommelin, D.J. et al. Eur. J. Hosp. Pharm. Sci. 1, 11-17 (2005).

12. Roger, S.D. Nephrology 11, 341-346 (2006).

13. Schellekens, H. Nephrol. Dial. Transplant. 20, 31-36 (2005).

14. <http://www.emea.europa.eu/humandocs/PDFs/EPAR/ Omnitrope/H-607-PI-en.pdf> (Accessed 4 March 2008)

15. <http://www.emea.europa.eu/humandocs/PDFs/EPAR/ valtropin/H-602-PI-en.pdf $>$ (Accessed 4 March 2008)

16. <http://www.emea.europa.eu/humandocs/PDFs/EPAR/ abseamed/H-727-en6.pdf> (Accessed 4 March 2008)

17. http://www.emea.europa.eu/humandocs/PDFs/EPAR/ binocrit/H-725-en6.pdf

18. <http://www.emea.europa.eu/humandocs/PDFs/EPAR/ epoetinalfahexal/H-726-en6.pdf> (Accessed 4 March 2008)

19. <http://www.emea.europa.eu/humandocs/PDFs/EPAR/ silapo/H-760-PI-en.pdf> (Accessed 4 March 2008)

20. <http://www.emea.europa.eu/humandocs/PDFs/EPAR/ retacrit/H-872-en6.pdf> (Accessed 4 March 2008)

21. <http://www.emea.europa.eu/humandocs/PDFs/EPAR/ Omnitrope/060706en6.pdf> (Accessed 4 March 2008)

22. <http://www.emea.europa.eu/humandocs/PDFs/EPAR/ valtropin/H-602-en6.pdf> (Accessed 4 March 2008)

23. <http://www.emea.europa.eu/humandocs/PDFs/EPAR/ Omnitrope/060706en6.pdf> (Accessed 4 March 2008)

24. <http://www.emea.europa.eu/humandocs/PDFs/EPAR/ valtropin/H-602-en6.pdf> (Accessed 4 March 2008)

25. <http://www.emea.europa.eu/humandocs/PDFs/EPAR/ epoetinalfahexal/H-726-en6.pdf> (Accessed 4 March 2008)

26. <http://www.emea.europa.eu/humandocs/PDFs/EPAR/ binocrit/H-725-en6.pdf>

27. <http://www.emea.europa.eu/humandocs/PDFs/EPAR/ abseamed/H-727-en6.pdf> (Accessed 4 March 2008)

28. <http://www.emea.europa.eu/humandocs/PDFs/EPAR/ silapo/H-760-en6.pdf> (Accessed 4 March 2008)

29. <http://www.emea.europa.eu/humandocs/PDFs/EPAR/ retacrit/H-872-en6.pdf> (Accessed 4 March 2008)

30. Anonymous. CHMP assessment report for Filgrastim Hexal (EMEA, London; 2008) <http://www.emea.europa. eu/humandocs/PDFs/EPAR/FilgrastimHexal/H-918-en6. pdf $>$ (Accessed 28 February 2009)

31. Anonymous. Questions and answers on recommendation for refusal of marketing application for alpheon. (EMEA London, 2006; accessed 3 March 2008). <http://www. emea.europa.eu/pdfs/human/opinion/19089606en. pdf>

32. Anonymous. Questions and answers on the withdrawal of the marketing authorisation application for Insulin Human Rapid Marvel; Insulin Human Long Marvel; Insulin Human 30/70 Mix Marvel. (EMEA, London; 2008; accessed 28 February 2008). <http://www.emea. europa.eu/humandocs/PDFs/EPAR/insulinhumanrapidm arvel/419308en.pdf>

33. Blanchette, F. \& Neuhaus, O. J. Neurol. 255 Suppl 1 , 26-36 (2008)

34. Toblli, J.E., Cao, G., Oliveri, L. \& Angerosa., M. Port. J. Nephrol. Hypert. 23, 53-63 (2009). 